\title{
Athletic Injuries of the Hip
}

Editors

DUSTIN L. RICHTER

F. WINSTON GWATHMEY

\section{CLINICS IN \\ SPORTS MEDICINE}

www.sportsmed.theclinics.com

Consulting Editor

MARK D. MILLER

April 2021 - Volume 40 - Number 2 